\title{
Estimating the Case Fatality Risk of COVID-19 using Cases from Outside China
}

\author{
Nick Wilson $^{1}$, Amanda Kvalsvig ${ }^{1}$, Lucy Telfar Barnard ${ }^{1}$, Michael G Baker ${ }^{1}$ \\ ${ }^{1}$ Department of Public Health, University of Otago Wellington, New Zealand \\ Correspondence: Prof Nick Wilson, nick.wilson@otago.ac.nz
}

\begin{abstract}
There is large uncertainty around the case fatality risk (CFR) for COVID-19 in China. Therefore, we considered symptomatic cases outside of China (countries/settings with 20+ cases) and the proportion who are in intensive care units $(4.0 \%, 14 / 349$ on 13 February 2020). Given what is known about CFRs for ICU patients with severe respiratory conditions from a meta-analysis, we estimated a CFR of $1.37 \%$ (95\%CI: $0.57 \%$ to $3.22 \%$ ) for COVID19 cases outside of China.
\end{abstract}

The new coronavirus (COVID-19) appears to be fairly transmissible [1], and is spreading in China. Disease severity is a particularly important parameter for understanding this new disease [1], but unfortunately, the case fatality risk (CFR) data from China is difficult to interpret owing to likely missed mild cases (including due to a lack of appropriate test kits early in the epidemic) and also the likely delay in deaths occurring. Such a prolonged time course is suggested by a case series of 138 cases from Wuhan, China with cases enrolled between 1-28 January 2020. For this group on 3 February, $62 \%$ were still hospitalised and $31 \%(11 / 36)$ of those admitted to ICU were still there (6 had died) [2].

In jurisdictions outside China (and excluding Hong Kong, Macao and Taiwan) the CFR as detailed in the 13 February WHO Report [3] was $1 / 447=0.22 \%$ (95\% confidence interval $(\mathrm{CI})=0.40 \%$ to $1.26 \%$ ). But this estimate also did not account for possible missed mild cases in those countries or the lag time between hospitalisation and death.

One possible way to get a better estimate of the CFR is to consider the proportion of cases currently in intensive care units (ICUs) in settings outside China where the healthcare system is working relatively normally (ie, is not over-burdened by the epidemic). As per Table 1 we estimated that $4.0 \%(14 / 349)$ of identified cases were in ICUs in all the countries outside of China that had $20+$ cases.

Table 1. Cases in countries and settings outside China with 20+ cases on 13 February 2020 and the proportion estimated to be in intensive care units

\begin{tabular}{|l|c|c|l|}
\hline $\begin{array}{l}\text { Country/ } \\
\text { setting }\end{array}$ & $\begin{array}{c}\text { Confirmed } \\
\text { cases as of } \\
\text { 13 February } \\
\text { [3] }\end{array}$ & $\begin{array}{c}\text { Estimated } \\
\text { proportion } \\
\text { in ICU }\end{array}$ & \multicolumn{1}{|c|}{ Comments and references for ICU occupancy } \\
\hline Singapore & 50 & $16 \%(8 / 50)$ & Based on a news report on 12 February [4]. \\
\hline Thailand & 33 & $\begin{array}{c}1 / 33 \\
\text { (assumed as } \\
\text { per "serious } \\
\text { condition") }\end{array}$ & $\begin{array}{l}\text { Based on a news report on 13 February [5]: "Confirmed } \\
\text { cases reached 33, including one person in serious } \\
\text { condition, by 12 February". }\end{array}$ \\
\hline
\end{tabular}

NOTE: This preprint reports new research that has not been certified by peer review and should not be used to guide clinical practice. 
medRxiv preprint doi: https://doi.org/10.1101/2020.02.15.20023499; this version posted February 18, 2020. The copyright holder for this preprint (which was not certified by peer review) is the author/funder, who has granted medRxiv a license to display the preprint in

It is made available under a CC-BY-NC-ND 4.0 International license .

\begin{tabular}{|c|c|c|c|}
\hline $\begin{array}{l}\text { Country/ } \\
\text { setting }\end{array}$ & $\begin{array}{l}\text { Confirmed } \\
\text { cases as of } \\
13 \text { February } \\
\text { [3] }\end{array}$ & $\begin{array}{l}\text { Estimated } \\
\text { proportion } \\
\text { in ICU }\end{array}$ & Comments and references for ICU occupancy \\
\hline Japan & 29 & $0 / 25$ & $\begin{array}{l}\text { Based on a translation of a Ministry of Health, Labour } \\
\text { and Welfare document on } 12 \text { February [6]. See below } \\
\text { for separate cruise ship data. }\end{array}$ \\
\hline $\begin{array}{l}\text { Republic of } \\
\text { Korea }\end{array}$ & 28 & $\begin{array}{c}0 / 23 \text { (see } \\
\text { comments) }\end{array}$ & $\begin{array}{l}\text { When there were } 23 \text { known cases: "all } 22 \text { patients } \\
\text { currently isolated are in stable condition....."one patient } \\
\text { was discharged from a hospital yesterday after he was } \\
\text { cured". Based on a news report on } 6 \text { February [7]. }\end{array}$ \\
\hline $\begin{array}{l}\text { International } \\
\text { conveyance - } \\
\text { (specifically } \\
\text { the cruise } \\
\text { ship } \\
\text { "Diamond } \\
\text { Princess" } \\
\text { moored in } \\
\text { Japan) }\end{array}$ & $\begin{array}{l}174 \text { (updated } \\
\text { to } 218 \text { later } \\
\text { on } 13 \\
\text { February - } \\
\text { see } \\
\text { comments) }\end{array}$ & $\begin{array}{l}5 / 218 \text { (see } \\
\text { comments) }\end{array}$ & $\begin{array}{l}\text { Based on a news report on } 13 \text { February [8]: "Kato said } \\
\text { five people from the ship are currently in serious } \\
\text { condition in hospital". A prior report on } 12 \text { February in } \\
\text { the same news source gave more detail for the first four } \\
\text { people where the Health Minister (Katsunobu Kato) was } \\
\text { reported saying: "At this point, we have confirmed that } \\
\text { four people, among those who are hospitalised, are in a } \\
\text { serious condition, either on a ventilator or in an intensive } \\
\text { care unit." [9] }\end{array}$ \\
\hline Total & & $\begin{array}{c}4.0 \% \\
(14 / 349)\end{array}$ & \\
\hline
\end{tabular}

Next we considered the typical survival of people admitted to ICUs with severe respiratory conditions. We used data from a meta-analysis of trials comparing higher vs lower levels of positive end-expiratory pressure (PEEP) in adults with acute lung injury or acute respiratory distress syndrome (ARDS) [10]. This study found 374 hospital deaths in 1136 patients (32.9\%) assigned to treatment with higher PEEP and 409 hospital deaths in 1163 patients (35.2\%) assigned to lower PEEP (with no significant difference between these two groups). Combining these data suggests a CFR in such patients with acute lung injury of $34.1 \%$ (783/2299). This estimate is a little less than one case series of ICU patients with acute respiratory failure from Influenza A $(\mathrm{H} 1 \mathrm{~N} 1)$ and requiring mechanical ventilation, who had a CFR of $46 \%$ (156/337) [11]. Another study of such ICU patients with influenza found a lower overall CFR of 26\% (492/1859) [12] and another one reported a CFR of $24 \%$ (177/733) [13]. Furthermore, in a group of 340 ICU patients with ARDS, the CFR at 90 days was $32 \%$ in a group given a neuromuscular blocker and $41 \%$ in the placebo group [14].

We then applied the $34.1 \%$ value from the meta-analysis to the data in Table 1, giving an estimated CFR of $1.37 \%$ ([14 x 34.1\%]/349) for COVID-19. The 95\% confidence interval (CI) of this estimate is $0.57 \%$ to $3.22 \%$. This estimate can be considered a symptomatic CFR (sCFR) as it likely to be based on a denominator who had symptoms and were tested and laboratory-confirmed as cases. This estimate is almost invariably higher than the infectionfatality risk (IFR) which can only be estimated when serological testing becomes available to identify all of those infected [15].

Decision-makers and disease modellers might still be best to assume that the 'true' CFR is less than our estimate here as mild cases may not be identified. Furthermore, if a specific treatment is identified in the near future, then cases could have improved survival and the CFR might decline. On the other hand, if health systems became overloaded with the COVID-19 epidemic, then the CFR could likely increase for both the community and in hospital cases. As there is further progression of the COVID-19 epidemic, ongoing work will be needed to better clarify both transmissibility and the CFR, so that the likely mortality 
medRxiv preprint doi: https://doi.org/10.1101/2020.02.15.20023499; this version posted February 18, 2020. The copyright holder for this preprint (which was not certified by peer review) is the author/funder, who has granted medRxiv a license to display the preprint in

It is made available under a CC-BY-NC-ND 4.0 International license .

burden can be estimated. The method we have used here for CFR estimation will only be valid prior to healthcare systems becoming overloaded, after which they are likely to change their ICU admission policies.

Our provisional CFR estimate for COVID-19 is less than that estimated for MERS-CoV and SARS-CoV, but is broadly comparable with two of the three previous influenza pandemics (when considering the range of estimated values) (Table 2).

Table 2. Case fatality risks for selected pandemics (by descending order of mid-range estimates of magnitude)

\begin{tabular}{|l|c|l|}
\hline Pandemic & CFR & \multicolumn{1}{|c|}{ Comments and references } \\
\hline $\begin{array}{l}\text { Middle East respiratory } \\
\text { syndrome coronavirus } \\
\text { (MERS-CoV) }\end{array}$ & $34.4 \%$ & WHO estimate [16]. \\
\hline $\begin{array}{l}\text { Severe acute respiratory } \\
\text { syndrome coronavirus } \\
\text { (SARS-CoV) }\end{array}$ & $9.6 \%$ & $\begin{array}{l}\text { Based on 8,096 reported cases, including 774 deaths in } \\
27 \text { countries (by July 2003) [17]. This could however be } \\
\text { an over-estimate given the possibility of mild cases not } \\
\text { being detected. }\end{array}$ \\
\hline $\begin{array}{l}\text { Pandemic influenza in } \\
1918-1919 \text { (United States } \\
\text { [US]) }\end{array}$ & $\begin{array}{c}0.5 \% \text { to } \\
5.3 \% \\
\text { depending } \\
\text { on age- } \\
\text { group }\end{array}$ & $\begin{array}{l}\text { Highest in those aged <1 year (at 5.2\%) and in the very } \\
\text { old (70 to 74 years, 5.3\%) [18]. Lowest in young children } \\
\text { (5 to 9 years, 0.5\%) and middle-aged adults (55 to 59 } \\
\text { years, 0.9\%). There was an intermediate peak in the CFR } \\
\text { among young adults (25 to 29 years, 3.1\%). }\end{array}$ \\
\hline $\begin{array}{l}\text { COVID-19 outside of China } \\
\text { (this study) }\end{array}$ & $\begin{array}{c}1.5 \%(0.6 \% \\
\text { to 3.5\%) }\end{array}$ & $\begin{array}{l}\text { These values could, however, be over-estimates given the } \\
\text { possibility of mild cases not being detected (see main } \\
\text { text). }\end{array}$ \\
\hline Pandemic influenza in 2009 & $\begin{array}{c}0 \% \text { to 1.2\% } \\
\text { (but mainly } \\
0.05 \% \text { to } \\
0.005 \%)\end{array}$ & $\begin{array}{l}\text { A systematic review considered 77 estimates from } 50 \\
\text { published studies [19]. The values for symptomatic cases } \\
\text { had point estimates ranging from 0 to 1,200 per 100,000 } \\
\text { cases. Nevertheless, "most of the estimates in this } \\
\text { category [symptomatic cases] fell in the range of 5 to 50 } \\
\text { deaths per 100,000 cases." }\end{array}$ \\
\hline $\begin{array}{l}\text { Pandemic influenza in 1957 } \\
\text { (US data) }\end{array}$ & $\begin{array}{l}0.2 \% \\
\text { Calculated using US data from: [20]. }\end{array}$ \\
\hline
\end{tabular}


medRxiv preprint doi: https://doi.org/10.1101/2020.02.15.20023499; this version posted February 18, 2020. The copyright holder for this preprint (which was not certified by peer review) is the author/funder, who has granted medRxiv a license to display the preprint in

It is made available under a CC-BY-NC-ND 4.0 International license .

\section{References}

1. Cowling BJ, Leung GM. Epidemiological research priorities for public health control of the ongoing global novel coronavirus (2019-nCoV) outbreak. Euro Surveill. 2020.

2. Wang D, Hu B, Hu C, Zhu F, Liu X, Zhang J, et al. Clinical Characteristics of 138 Hospitalized Patients With 2019 Novel Coronavirus-Infected Pneumonia in Wuhan, China. JAMA. 2020.

3. World Health Organization. Coronavirus disease 2019 (COVID-19) Situation Report - 24. (13 February 2020). [Accessed 13 Feb 2020]. Available from: https://www.who.int/docs/default-source/coronaviruse/situation-reports/20200213sitrep-24-covid-19.pdf?sfvrsn=9a7406a4 4 .

4. Xinghui K. Coronavirus: 'some people may succumb', says Singapore as cases hit 50. This Week in Asia (12 February 2020). [Accessed 13 Feb 2020]. Available from: https://www.scmp.com/week-asia/health-environment/article/3050308/coronavirussome-people-may-succumb-says-singapore.

5. Duddu P. Coronavirus in Thailand: dealing with the 2019-nCoV (Covid-19) outbreak and impact. Pharmaceutical Technology (13 February 2020). [Accessed 13 Feb 2020]. Available from: https://www.pharmaceutical-technology.com/features/coronavirusaffected-countries-thailand-measures-impact-tourism/.

6. Ministry of Health LaW. About the present situation of new type coronavirus infectious disease and correspondence of Ministry of Health, Labor and Welfare (February 12, 1921 version). [Accessed 13 February 2020]. Available from: https://www.mhlw.go.jp/stf/newpage_09450.html?fbclid=IwAR3t1NdoMXaCg2r5m3 u9Bsxx3NezQQYuF2Avsgsr74yJ6eFQfjUI13wwLIM.

7. Chang R. Coronavirus infections in S. Korea rise to 23 after 4 more confirmed cases. TBS eFM News (6 February 2020). [Accessed 13 Feb 2020]. Available from: http://tbs.seoul.kr/eFm/newsView.do?typ_800=N\&idx_800=2383979\&seq_800 $=$.

8. AFP. Japan cruise ship virus cases jump to 218. Bangkok Post (13 February 2020). [Accessed 13 Feb 2020]. Available from: https://www.bangkokpost.com/world/1856719/japan-cruise-ship-virus-cases-jump-to218\#cxrecs_s.

9. AFP. Japan cruise ship coronavirus cases climb to 174. Bangkok Post (12 February 2020). [Accessed $13 \mathrm{Feb} 2020]$. Available from: https://www.bangkokpost.com/world/1855919/japan-cruise-ship-coronavirus-casesclimb-to-174.

10. Briel M, Meade M, Mercat A, Brower RG, Talmor D, Walter SD, et al. Higher vs lower positive end-expiratory pressure in patients with acute lung injury and acute respiratory distress syndrome: systematic review and meta-analysis. JAMA. 2010;303(9):865-873.

11. Estenssoro E, Rios FG, Apezteguia C, Reina R, Neira J, Ceraso DH, et al. Pandemic 2009 influenza A in Argentina: a study of 337 patients on mechanical ventilation. Am J Respir Crit Care Med. 2010;182(1):41-48.

12. Louie JK, Yang S, Acosta M, Yen C, Samuel MC, Schechter R, et al. Treatment with neuraminidase inhibitors for critically ill patients with influenza A (H1N1)pdm09. Clin Infect Dis. 2012;55(9):1198-1204.

13. Martin-Loeches I, Bermejo-Martin JF, Valles J, Granada R, Vidaur L, VergaraSerrano JC, et al. Macrolide-based regimens in absence of bacterial co-infection in critically ill H1N1 patients with primary viral pneumonia. Intensive Care Med. 2013;39(4):693-702. 
medRxiv preprint doi: https://doi.org/10.1101/2020.02.15.20023499; this version posted February 18, 2020. The copyright holder for this preprint (which was not certified by peer review) is the author/funder, who has granted medRxiv a license to display the preprint in It is made available under a CC-BY-NC-ND 4.0 International license .

14. Papazian L, Forel JM, Gacouin A, Penot-Ragon C, Perrin G, Loundou A, et al. Neuromuscular blockers in early acute respiratory distress syndrome. N Engl J Med. 2010;363(12):1107-1116.

15. Lipsitch M, Donnelly CA, Fraser C, Blake IM, Cori A, Dorigatti I, et al. Potential biases in estimating absolute and relative case-fatality risks during outbreaks. PLoS Negl Trop Dis. 2015;9(7):e0003846.

16. World Health Organization. Middle East respiratory syndrome coronavirus (MERSCoV). [Accessed 13 Feb 2020]. Available from: https://www.who.int/emergencies/mers-cov/en/.

17. de Wit E, van Doremalen N, Falzarano D, Munster VJ. SARS and MERS: recent insights into emerging coronaviruses. Nat Rev Microbiol. 2016;14(8):523-534.

18. Brundage JF. Cases and deaths during influenza pandemics in the United States. Am J Prev Med. 2006;31(3):252-256.

19. Wong JY, Kelly H, Ip DK, Wu JT, Leung GM, Cowling BJ. Case fatality risk of influenza A (H1N1pdm09): a systematic review. Epidemiology. 2013;24(6):830-841.

20. Qualls N, Levitt A, Kanade N, Wright-Jegede N, Dopson S, Biggerstaff M, et al. Community Mitigation Guidelines to Prevent Pandemic Influenza - United States, 2017. MMWR Recomm Rep. 2017;66(1):1-34. 